\title{
How uncertainty and firm characteristics determine the capital structure: Evidence from Indonesia's sharia- and non-sharia-compliant firms
}

\author{
M.L. Nurhakim \& I. Gandakusuma \\ Master of Management, Universitas Indonesia, Jakarta, Indonesia
}

\begin{abstract}
This paper inspects the determinants of the capital structure of Indonesia's shariaand non-sharia-compliant firms. We employed a broader and more comprehensive uncertainty index than Economic Policy Uncertainty (EPU) called the World Uncertainty Index (WUI). This study derived results from a static panel data model that allows for interactions between the uncertainty index and firm characteristics. Our findings unveil that some WUI and firm characteristic interactions are statistically significant to determine the sharia-compliant firm capital structure. Interestingly, some sharia-compliant firm characteristics are insignificant individually, but significantly affect the capital structure when dealing with uncertainty. The results show that firm characteristics have a partial effect on the non-sharia-compliant firm capital structure. This study extends the empirical literature of the uncertainty index and becomes the pioneer in research, employing the newly introduced WUI in sharia firms and emerging markets.
\end{abstract}

\section{INTRODUCTION}

Capital structure plays an important role in fulfilling stakeholders' needs. Capital structure is also the main topic in corporate finance, and its study remains inconclusive (Vo, 2017; Yildirim et al., 2018). As sharia finance in Indonesia is growing, especially in the sharia-compliant firms, the urgency of capital structure studies in this type of firm is increases. Besides, Indonesia was also recognized as the best sharia capital market in 2019 and 2020. Sharia-compliant firms are listed in Indonesia's Financial Authority (OJK) list of sharia effect called Daftar Efek Syariah (DES). Sharia-compliant firms in Indonesia's Stock Exchange (BEI) share 50\% of the capital market, and $63 \%$ of the stocks in BEI is sharia-compliant firms. Thus, the capital structure topic is becoming increasingly important for the stakeholders, as the sharia market grows.

In this study, we employed the World Uncertainty Index (WUI), introduced by Ahir, Bloom, and Furceri in 2018. As suggested by Li \& Qiu (2021), we used the WUI with firm characteristics to extract its effect on the capital structure. We employed profitability, firm size, tangibility, and growth opportunity as the firm characteristics. The research questions are determinants of capital structure in both sharia-compliant firms and non-sharia-compliant firms. We also investigated the effect of the uncertainty index on the capital structure. The rest of the paper are as follows: section 2 - literature review, section 3-methodology, section 4-results, and section 5-conclusions.

\section{LITERATURE REVIEW}

Sharia-compliant firms enlisted in DES are limited to firms that are stated in its articles of association bylaws about business conduct under sharia principles or are reporting certain levels of debt 
and non-halal revenue sources. These limitations may drive the capital structure approach of such firms in different ways. The main theories to explain the capital structure approach is trade-off and pecking order (Yildirim et al., 2018). Trade-off indicates that financial mix is to adjust the tax shield and various costs of issuing debt (Myers, 1984). Pecking order theory provides hierarchy options for financing decisions and firms issue the most secure external financing if required (Myers, 1984). Trade-off and pecking order are quite different. Trade-off tends to leverage the firm's capability, while pecking order opts for external financing only if necessary.

WUI is an uncertainty index covering political and economic uncertainty (Ahir et al., 2018). The previously used uncertainty index was the Economic Policy Uncertainty (EPU), which covered economic uncertainty and was available for developed countries only. The WUI is a development of this index and is now available for emerging countries. The WUI is correlated negatively with macroeconomics indicators (e.g., GDP) and is suggested by the developer to be used as an alternative macroeconomic variable (Ahir et al., 2018).

\section{METHODOLOGY}

\subsection{Sample design}

We employed the list of the sharia effect or called Daftar Efek Syariah (DES) published by OJK and Sharia National Board in the 2015-2019 period. Sharia-compliant firms' sample was collected by including firms that were always listed in DES in 2015-2019. Non-sharia-compliant firms' sample was collected by including all firms that were always out of the DES during the same period. The sample excluded the financial industry and all firms which were either inconsistently present in the list or not present at all during the period. This exclusion becomes the limitation of this study, as it may not explain all of the firms in the exchange. We collected 163 sharia-compliant firms and 51 non-sharia-compliant firms.

We employed book leverage and market leverage for the capital structure indicator. Profitability was measured by EBITDA to TA; firm size was measured by the natural logarithm of revenue; tangibility was measured by PPE to TA; and growth opportunity was measured by the market to book ratio. GDP was measured by its annual growth and WUI was measured by its natural logarithm. These variables were collected from Thomson Reuters data stream, world bank, and EPU.

\subsection{Model specification}

The model in this study is based on two main reasons as previous studies suggested. The first reason is mitigation of the endogeneity problem. The second reason is that Yildirim et al. (2018) stated a common belief in the studies in which firm characteristics affect capital structure decisions at least in the following year. Li \& Qiu (2021) also stated that the uncertainty index or macroeconomic variables are likely to affect the leverage at least in the subsequent year. Incorporating the static panel regression and prior considerations, we estimate:

$$
\begin{aligned}
& B L E W_{i t}=\alpha+\beta_{1} \text { PROF }_{i t-1}+\beta_{2} \text { SIZE }_{i t-1}+\beta_{3} \text { TANG }_{i t-1}+\beta_{4} \text { GOPP }_{i t-1}+\beta_{5} L W U I_{i t-1} \\
& +\beta_{6} L_{W U I_{i t-1}}{ }^{*} \text { PROF }_{i t-1}+\beta_{7} L_{W U I_{i t-1}}{ }^{*} \operatorname{SIZE}_{i t-1}+\beta_{8} L_{W U I_{i t-1}}{ }^{*} T A N G_{i t-1} \\
& +\beta_{9} L W U I_{i t-1}{ }^{*} G O P P_{i t-1}+\beta_{10} G D P G_{i t-1}+\mu_{1}+\mu_{t}+\varepsilon_{i t} \\
& M L E W_{i t}=\alpha+\beta_{1} P_{R O F_{i t-1}}+\beta_{2} \text { SIZE }_{i t-1}+\beta_{3} T_{A N G_{i t-1}}+\beta_{4} G O P P_{i t-1}+\beta_{5} L W U I_{i t-1} \\
& +\beta_{6} L_{W U I_{i t-1}}{ }^{*} \text { PROF }_{i t-1}+\beta_{7} L_{W U I_{i t-1}}{ }^{*} \operatorname{SIZE}_{i t-1}+\beta_{8} L W U I_{i t-1}{ }^{*} T A N G_{i t-1} \\
& +\beta_{9} L W U I_{i t-1}^{*} G O P P_{i t-1}+\beta_{10} G D P G_{i t-1}+\mu_{i}+\mu_{t}+\varepsilon_{i t}
\end{aligned}
$$




\section{RESULTS}

\subsection{Results}

Before the estimation of the results, we conducted a model selection procedure for all 4 models (book leverage and market leverage for both sharia and non-sharia). The selection process also considered the validity of the regression after facing the autocorrelation and heteroskedasticity issue. As suggested by Schaffer and Stillman (2006), we tested for overidentifying to choose the model with robust-cluster standard error. Given below is the summary.

Table 1. Static panel regression results

\begin{tabular}{|c|c|c|c|c|}
\hline \multirow[b]{3}{*}{ Variable } & \multicolumn{2}{|c|}{ Book Leverage } & \multicolumn{2}{|c|}{ Market Leverage } \\
\hline & Sharia & Non-sharia & Sharia & Non-sharia \\
\hline & Coefficient & Coefficient & Coefficient & Coefficient \\
\hline L1.PROF & 0.0916 & -0.2454 & 0.3750 & -0.2310 \\
\hline L1.SIZE & $0.0262^{* *}$ & $0.0628^{* *}$ & 0.0090 & 0.0320 \\
\hline L1.TANG & -0.1837 & -0.0465 & 0.0860 & 0.1230 \\
\hline L1.GOPP & 0.0031 & -0.0173 & $-0.0560^{* * *}$ & $-0.0680^{* *}$ \\
\hline L1.LWUI & -0.0538 & 0.0922 & 0.0090 & 0.0290 \\
\hline L1.LWUIXPROF & $0.0840^{* *}$ & 0.1569 & $0.1830^{* *}$ & 0.7170 \\
\hline L1.LWUIXSIZE & 0.0046 & -0.0055 & -0.0010 & -0.0030 \\
\hline L1.LWUIXTANG & -0.0495 & -0.0291 & 0.0090 & 0.0130 \\
\hline L1.LWUIXGOPP & -0.0018 & -0.0073 & $-0.0090^{* * *}$ & -0.0050 \\
\hline L1.GDPG & 53.7200 & 92.0400 & $16.5370^{* * *}$ & 44.7900 \\
\hline Constant & -0.1598 & -0.6873 & -0.4940 & -0.0470 \\
\hline $\mathrm{R} 2$ & 0.0823 & 0.1198 & 0.205 & 0.4271 \\
\hline F-stat & $3.65^{* * *}$ & $7.02^{* * *}$ & $5.700^{* * *}$ & $83.49^{* * *}$ \\
\hline Observations & 715 & 255 & 715 & 255 \\
\hline Model & Fixed effect & Fixed effect & Fixed effect & Random Effect \\
\hline
\end{tabular}

${ }^{*}, * *$ and ${ }^{* * *}$ denote significance at $10 \%, 5 \%$, and $1 \%$ levels respectively.

From Table 1, we found consistency with previous studies in the importance of size and growth opportunity in firms' capital structure decision (Moradi \& Paulet, 2019; Onofrei et al., 2015; Rokhayati et al., 2019; Vo, 2017; Yildirim et al., 2018; Zhang et al., 2018). Both size and growth's effect can be explained by the trade-off theory since both factors are indicating the firm's capability to endure the risk of leverage. From the size point of view, the positive relationship is the cause of increasing capability to endure more risk as the firm's getting bigger in size. Therefore, a firm with a bigger size tends to increase leverage. High growth opportunity indicates higher risk, and firms tend to lower the leverage as the growth opportunity increases.

Profitability is not significantly affecting leverage and is consistent with previous studies (Moosa \& Li, 2012; Oktavina \& Manalu, 2018; Rokhayati et al., 2019). We may argue that profitability may not indicate the needs for external financing, yet it shows the cash availability. Tangibility is also not significant and is consistent with previous studies (Fauzias et al., 2011; Moosa \& Li, 2012; Serrasqueiro \& Caetano, 2015; Yildirim et al., 2018). Fauzias et al. (2011) compared the tangibility between countries and found it insignificant due to the assumptions of firms in different countries regarding the importance of tangibility.

Comparing our study results with those reported by Li and Qiu (2021), we found that the uncertainty index indicated by WUI is not significant. Li and Qiu (2021) also found it insignificant in two of three uncertainty indexes they employed. We also confirm the significant interaction between firm characteristics (profitability and growth opportunity) with the uncertainty index, 
although we only found one firm characteristic that is partially significant through interaction, namely, the growth opportunity.

The effect of the interaction is also as expected, where the index's effect is the same as the firm characteristic it interacted with.

\section{CONLUSION}

In conclusion, we found that determinants of the capital structure of both sharia-compliant and non-sharia compliant firms are size and growth opportunity in terms of the firm's characteristics. Comparing the results of the two types of firms, the significant firm's characteristics are affecting the capital structure similarly. The uncertainty index effects on capital structure are seen through its interaction with growth opportunity and profitability only to sharia-compliant firms and are partially insignificant on both types. The interaction effects indicate that firms are considering external factors and internal factors when deciding financial mix. The indifference effects may indicate a similar managerial approach on both firm types. It may also concern the policymakers on how to regulate the different types of firms as they show quite a similar approach to capital structure decisions. Further, this may also raise a question for investors regarding the difference between sharia-compliant and non-sharia-compliant firms since sharia-compliant firms are facing more constraints than non-sharia-compliant firms. Results in this study also show that firms are rational when deciding their financing and the firm's risks. For further studies, the researcher may employ uncertainty index in another related topic or provide a comparative study between countries, since it is available for both emerging and developed countries.

\section{REFERENCES}

Ahir, H., Bloom, N., \& Furceri, D. (2018). The World Uncertainty Index. SSRN Electronic Journal. https://doi.org/10.2139/ssrn.3275033.

Fauzias, M. N., Razali, H., Khairunisah, I., Izani, I., \& Norazlan, A. (2011). Determinants of Target Capital Structure: Evidence on South East Asia Countries Nor, Haron, Ibrahim, Ibrahim \& Alias. Journal of Business and Policy Research, 6(3), 39-61.

Li, X., \& Qiu, M. (2021). Journal of International Money and Finance The joint effects of economic policy uncertainty and firm characteristics on capital structure?: Evidence from US firms. Journal of International Money and Finance, 110, 102279. https://doi.org/10.1016/j.jimonfin.2020.102279.

Moosa, I., \& Li, L. (2012). Firm-specific factors as determinants of capital structure: Evidence from Indonesia. Review of Pacific Basin Financial Markets and Policies, 15(2), 1-17. https://doi.org/ 10.1142/S021909151150007X.

Moradi, A., \& Paulet, E. (2019). The firm-specific determinants of capital structure - An empirical analysis of firms before and during the Euro Crisis. Research in International Business and Finance, 47(July 2018), 150-161. https://doi.org/10.1016/j.ribaf.2018.07.007.

Myers, S. C. (1984). The Capital Structure Puzzle. The Journal of Finance, XXXIX(3), 575-592.

Oktavina, M., \& Manalu, S. (2018). Pecking Order and Trade-off Theory in Capital Structure Analysis of Family Firms in Indonesia. Jurnal Keuangan Dan Perbankan, 22(1), 73-82. https://doi.org/ 10.26905/jkdp.v22i1.1793.

Onofrei, M., Tudose, M. B., Durdureanu, C., \& Anton, S. G. (2015). Determinant Factors of Firm Leverage: An Empirical Analysis at Iasi County Level. Procedia Economics and Finance, 20(15), 460-466. https://doi.org/10.1016/s2212-5671(15)00097-0

Rokhayati, I., Pramuka, B. A., \& Sudarto. (2019). Optimal financial leverage determinants for smes capital structure decision making: Empirical evidence from Indonesia. International Journal of Scientific and Technology Research, 8(11), 1155-1161.

Schaffer, M., \& Stillman, S. (2006). XTOVERID: Stata module to calculate tests of overidentifying restrictions after xtreg, xtivreg, xtivreg2, xthtaylor. Statistical Software Components.

Serrasqueiro, Z., \& Caetano, A. (2015). Trade-Off Theory versus Pecking Order Theory: capital structure decisions in a peripheral region of Portugal. J. Bus. Econ. Manage, 16(2), 445-466. 
Vo, X. V. (2017). Determinants of capital structure in emerging markets: Evidence from Vietnam.

Research in International Business and Finance, 40, 105-113. https://doi.org/10.1016/j.ribaf.2016.12.001

Yildirim, R., Masih, M., \& Bacha, O. I. (2018). Determinants of capital structure: evidence from Shari'ah compliant and non-compliant firms. Pacific Basin Finance Journal, 51(May), 198- 219. https://doi.org/10.1016/j.pacfin.2018.06.008

Zhang, Q., Saqib, Z. A., \& Chen, Q. (2018). Determinants of Capital Structure: An Empirical Analysis of Fuel and Energy Sector of Pakistan. 2018 15th International Conference on Service Systems and Service Management. https://doi.org/10.1109/ICSSSM.2018.8465061 